(1)(b). There is no such name as Ptinus Geoffroy, 1762. The name Ptilinus appears on p. 64 of Geoffroy (1762). This is not, as suggested by Thompson, an 'incorrect original spelling' of Ptinus sensu Linnaeus, 1767, but is an entirely different nominal genus which is considered in detail by Kerzhner (BZN 48: 123). Ptilinus is placed in the family ANOBIIDAE.

(1)(c). As pointed out by Borowiec (BZN 45: 194, para. 4) and Gentry in her comment above, Mylabris sensu Geoffroy (1762) is a senior synonym of Bruchus Linnaeus, 1767, whereas Mylabris Fabricius, 1775 (type species Meloe cichorii Linnaeus, 1758 by Latreille's (1810) designation) is in the MELOIDAE. It would be taxonomically confusing to attribute the meloid (oil beetle) generic name to Geoffroy.

(2) and (3). Drawbacks to these proposals by Thompson are implicit in the above.

(4). As mentioned above, Ptilinus Geoffroy, 1762 is not an incorrect spelling of the name Ptinus. The conservation of the names Bruchus Linnaeus, 1767, Ptinus Linnaeus, 1767 and Mylabris Fabricius, 1775, threatened by senior synonyms and/or homonyms which first appeared in Geoffroy (1762), has been proposed by Borowiec (BZN 45: 194-196); this course has been supported by Kerzhner (BZN 48: 107-134) and by Kerzhner \& Kirejtshuk in their comment above. Dr Borowiec's objective of conserving long-established usage can be achieved, and protracted discussion of the first available authorship of the names Bruchus and Mylabris in another taxonomic sense be avoided, by substituting the following for proposals (1) and (5) on BZN 45: 195.

The International Commission on Zoological Nomenclature is asked:

(1) to use its plenary powers to suppress the following generic names for the purposes of both the Principle of Priority and the Principle of Homonymy:

(a) Bruchus Geoffroy in Müller, 1764 and all uses of the name Bruchus prior to the publication of Bruchus Linnaeus, 1767;

(b) Mylabris Geoffroy in Müller, 1764 and all uses of the name Mylabris prior to the publication of Mylabris Fabricius, 1775;

(5) to place on the Official Index of Rejected and Invalid Generic Names in Zoology the following names:

(a) Bruchus Geoffroy in Müller, 1764, as suppressed in (1)(a) above;

(b) Mylabris Geoffroy in Müller, 1764, as suppressed in (1)(b) above.

\title{
Comments on the need for stability in fish family-group names
}

(See BZN 47: 97-100, 138)

(1) J.S. Nelson

Department of Zoology, Faculty of Science, University of Alberta, Edmonton, Canada T6G $2 E 9$

I fully agree with Alwyne Wheeler's comments. He made a strong case and presented it well.

In preparing my new edition (1984) of Fishes of the world it was not originally my intention to follow Steyskal (1980) but, seeing in the immediately preceding few years certain colleagues following his recommendations, I reluctantly (and regrettably) 
accepted most of his changes. I wrote a paragraph on my reluctance and a listing of those changes not accepted (1984, Preface, p. viii).

I consider that Wheeler has done a valuable service in presenting his views.

\section{Additional reference}

Nelson, J.S. 1984. Fishes of the world, Ed. 2. xv, 523 pp. Wiley \& Sons, New York.

(2) P.J. Miller

Department of Zoology, The University, Bristol BS8 1UG, England, U.K.

I should like to express my strong support for Alwyne Wheeler's views on this matter. The situation described by Wheeler, resulting from the strict application of Latin grammar by Steyskal (1980), is absolutely ridiculous, and quite out of keeping with the Code's main aim of stability in nomenclature. There should be a blanket decision by the Commission, rejecting all the changes made by Steyskal.

\section{Comment on the proposed precedence of HOMALOPTERIDAE Bleeker, 1859 over Balitoridae Swainson, 1839 (Osteichthyes, Cypriniformes) \\ (Case 2703; see BZN 47: 277-279)}

Peter K.L. Ng \& Kelvin K.P. Lim

Department of Zoology, National University of Singapore, Lower Kent Ridge Road, Singapore 0511

We do not agree with Hieronimus's proposal to give HOMALOPTERIDAE Bleeker, 1859 precedence over Balitoridae Swainson, 1839. We do not believe that changing the name from HOMALOPTERIDAE to BALITORIDAE will cause any confusion among scientists and seriously doubt its impact in popular circles.

Hieronimus (para. 3) states that 'Kottelat (1988, p. 489) himself admits that the replacement of HOMALOPTERIDAE by BALITORIDAE creates additional confusion in the suborder Cobitoidei. I cannot follow Kottelat in his opinion that an immediate introduction of the family-group name BALITORIDAE, which had been overlooked for about 150 years, would help to create a stable nomenclature'. This is erroneous and misleading. Kottelat actually wrote: 'Considering recent and expected changes in systematics and nomenclature in Cobitoidei... replacement of HOMALOPTERIDAE with BALITORIDAE should not create much additional confusion. Conservation of HOMALOPTERIDAE would be possible only by use of the plenary powers by the International Commission on Zoological Nomenclature. This would require a long procedure and thus, immediate introduction of the valid name better helps to create a stable nomenclature'. Kottelat's rationale behind not applying to the Commission was precisely to avoid the nomenclatural problems the family name of the torrent loaches now faces: whether it is to be Balitoridae according to the Principle of Priority, or HOMALOPTERIDAe following Article 79. Hieronimus appears to have misunderstood Kottelat's action and a problem faced by all taxonomists engaged in revisionary studies. If the intention is 


\section{$2 \mathrm{BHL}$ Biodiversity Heritage Library}

Nelson, J S. 1991. "Comments On The Need For Stability In Fish Family group Names." The Bulletin of zoological nomenclature 48, 147-148.

https://doi.org/10.5962/bhl.part.701.

View This Item Online: https://www.biodiversitylibrary.org/item/44489

DOI: https://doi.org/10.5962/bhl.part.701

Permalink: https://www.biodiversitylibrary.org/partpdf/701

\section{Holding Institution}

Natural History Museum Library, London

\section{Sponsored by}

Natural History Museum Library, London

\section{Copyright \& Reuse}

Copyright Status: In copyright. Digitized with the permission of the rights holder.

License: http://creativecommons.org/licenses/by-nc-sa/3.0/

Rights: https://biodiversitylibrary.org/permissions

This document was created from content at the Biodiversity Heritage Library, the world's largest open access digital library for biodiversity literature and archives. Visit BHL at https://www.biodiversitylibrary.org. 